\title{
ACCOUNTING EDUCATION : THE ROLE OF UNIVERSITIES IN IMPARTING SUSTAINABILITY ACCOUNTING KNOWLEDGE TO THE STAKEHOLDERS THROUGH INDUSTRY LINKAGE
}

\author{
S. Onyango ${ }^{1}$, S.W. Muchina ${ }^{2}$, and S.I. Ng'ang'a ${ }^{3}$ \\ ${ }^{I}$ Department of Business Management, School of Business, Karatina University, Kenya \\ ${ }^{2}$ Department of Business \& Entrepreneurship, School of Business, Karatina University, Kenya \\ ${ }^{3}$ Finance, Administration \& Planning at Garissa University College
}

\begin{abstract}
In the wake sustainability agendas that lead to green growth in the developing countries, the focus has been in the practice and accounting for Social, Environmental and Economic (SEE) activities by both processing and manufacturing organizations. Organizations practice social responsibilities with the view of reaping long term returns or merely complying with regulations, information which is obtained from their annual reports via various media. These reports however, in the purview of knowledge are very scanty and whether the stakeholders understand and are aware of this sustainability accounting information remain very uncertain. However, organizations lack requisite capacity to unfold the elements of sustainability accounting and concurrently develop stakeholder knowledge. This gap remains unbridged since it is debatable how universities shall collate such knowledge and disseminate it to the users of accounting information (stakeholders). Therefore, there is need to develop sustainability accounting knowledge through university industry linkages that will further the realization of sustainability agenda. The paper is based on business sustainability model which looks at sustainability accounting issues. The study was informed by primary data collected from 93 factory unit managers and accountants sampled from 31 tea factories around Mount Kenya region, in testing the relationship between social reporting, environmental reporting, and sustainability accounting in regard to stakeholder theory. The study established significant relationship between the variables (social reporting, environmental reporting and sustainability accounting) and concludes that green growth need to be enhanced through sustainability accounting. In order to foster this, concrete knowledge has to be created by universities that conduct research by linking with industries and disseminate the knowledge to the stakeholders for awareness through stakeholder conferences and publications. The university curriculum need therefore, to incorporate the sustainability issues and passing to the learners too.
\end{abstract}

Keywords: Social Reporting, Environmental Reporting, Stakeholder Knowledge, Sustainability Agenda, Universities, Economic activities

\section{INTRODUCTION}

There has been a drift of Millennium Development Goals (MDGs) to Sustainable Development Goals (SDGs)(United Nations Development Programme (UNDP), 2015). Perhaps, this has been driven by global economic storm subsisting of depleting natural resources, glaring population growth, environmental disasters, climate change and threat to human life in continued production(Sahd \& Rudman, 2012). Sustainable agenda is being embedded everywhere in the 
world both by developed and less developed countries(United Nations General Assembly (UNGA), 2015). The focus in these goals have been that main domain of the agenda is that social, environmental and economic activities are interconnected and such interplay cannot be achieved until sustainability agenda is first outlined at macroeconomic level as the practice in Czech Republic in Europe(Milan, 2009) and also at microeconomic level.Some world countries like Denmark, Finland, Japan, Korea, France, Pakistan, US, UK, Malysia and Canada have to some extent mandatory environmental reporting(Ernest \& Young (EY), 2014). India's Companies Act (2012) requires companies to spend $2 \%$ of declared net profit on Corporate Social Responsibility (CSR), this apply to almost 9000 companies. In 2013, European Union proposed non-financial reporting for large companies (EY, 2014). In Africa, sustainability has been driven by Gaborone Declaration that formed a transformative platform for achieving greener economy through Natural Capital Accounting(Reuter, Juhn, Portela, \& Venter, 2016).South Africa was the first country in Africa that required integrated accounting reporting from listed companies(EY, 2014). In Kenya, companies trading in Nairobi Stock Exchange (NSE) practiced social and environmental accounting, which is statistically on a rising trend where $60 \%$ practiced it in 2011, 63\% in 2012 and 68\% in 2013(Odhiambo, 2015). This shows the growing pressure on organizations to practice and report for integrated accounting that involves social, environmental and economic activities; to the stakeholders. One question remains, does the stakeholder care about this information and what is the role of universities to create such knowledge and educate the stakeholders?

\section{Problem Statement}

In the wake sustainability agendas that lead to green growth in the developing countries, the focus has been in the practice and accounting for Social, Environmental and Economic (SEE) activities by both processing and manufacturing organizations(Parkin et. al. 2003). This means that sustainability relates to accounting courses that include financial accounting, management accounting, cost accounting and auditing and assurance(Wolcott, 2010). Financial, sustainability and integrated reporting differ in the accounting principles(Wolcott, 2010). Organizations practice social responsibilities with the view of reaping long term returns since social performance indicator impact on financial performance (Supriti \& Damodar, 2010; Lin, Chang, \& Van, 215), intangible assets like human capital (Russo \& Fouts, 1997)and good will(Cheng, Laonnis, \& Serafeim, 2014); or merely complying with regulations, information which is obtained from their annual reports via various media. These reports however, in the purview of knowledge are very scanty and whether the stakeholders understand and are aware of this sustainability accounting information remain very uncertain. However, organizations lack requisite capacity to unfold the elements of sustainability accounting and concurrently develop stakeholder knowledge. This gap remains unbridged since it is debatable how universities and other higher learning institutions shall collate such knowledge and disseminate it to the users of accounting information (stakeholders).

\section{Objectives of the Study}

The objectives of the study was to:

i) establish the association between social reporting and sustainability accounting

ii) determine the association between environmental reporting and sustainability accounting

iii) establish the relationship between social reporting, environmental reporting and sustainability accounting within precincts of accounting education 


\section{LITERATURE REVIEW}

This sections contains reviewed literature in accounting education, stakeholder and role of the university in linking stakeholders and accounting education. It further reviews connection of accounting education and social constructivism theory of learning; and conceptual review on social reporting, environmental reporting and sustainability accounting and builds a conceptual framework out of it.

\section{Accounting Education, Stakeholders and the role of Universities}

The dynamism with which the business environment has grown into requires a change in which higher education pass knowledge of accounting of the generally known book keeping(Robson, Savage, \& Schffer, 2003). Accounting education(Benn \& Martin, 2010) need hence to conform to the changes in business environment hence research(Dyllick \& Hockerts, 2002) is important for accounting development and improvement(Wright \& Chalmers, 2010). The research should hence improving accounting education (Mandilaset al. 2016). These research findings can only meet business acumen if such research are conducted by universities.

Sustainability accounting can be brought forth in ways like leaders imposing sustainability agenda to the employees according to the firm's orientation or scholars use their sustainability knowledge to inform(Golsorkhi, Leca, Lounsbury, \& Ramirez, 2009) stakeholders. Stakeholder engagements can be manifested through focus engagement activity, stakeholder dialogue, investor engagement senior management dialogue(Wolcott, 2010). Large scale enterprises set up structures for stakeholder participation as forms of organization's democracy. This forms a potential forum for sustainable development; however, such enterprises still lack the requisite material and resources to develop knowledge and educate stakeholders of the organization's sustainability engagements through sustainability accounting and management(Schneider, 2015).

In the view of Higher Education Partnerships for Sustainability (HEPS), universities play three key roles which include being the institutions that create knowledge and inform leaders and the decision makers through research, development and teaching; managers of prudential resource use to not only achieve efficiency but also to build reputation; the source of human capital and consumers of products(Parkin et. al. 2003).In order to achieve this role, universities need to foster individual work programmes, have capacity building, link with industries, and develop framework for sustainability reporting(Parkin et. al. 2003). The major areas that universities need to concentrate on are training, research and development while developing workable and communication tools for accounting education, including strategies to review such information(Milan, 2009).

(Sonja et al. 2016) assert that universities like Appalachian State University, Arizona State University, Berridji State University, Carlifonia State University, Clark University, Idaho State University University of Idaho among others are striving ahead of time by offering courses dedicated to sustainability accounting in order to keep pace with the demand of integrated reporting expertise(Schaltegger \& Burritt, Sustainability Accounting for Companies. Catchphrase or Decision Support for Leaders, 2010). However, these knowledge are left with accounting graduates who might not quickly secure jobs and disseminate or practice them to the stakeholders given that the financial reporting remains dominant. This study hence directs universities to be driven by optimism and use social constructivism theory to impart knowledge on stakeholders for effective practice of social reporting, environmental reporting and economic reporting; even as they incorporate the sustainability accounting into curriculum. This is so since universities bear the capacity to creating sustainability environment(Marx \& Van der Watt, 2013). 


\section{Social Constructivism Theory}

Social constructivism theory posits that knowledge is created jointly by group of individuals. The theory states that understanding, meaning and significance of various phenomena of the world are developed through human coordination. The theory assumes that human being's experience are rationalized through social perspectives and that there is a language from which human beings coil reality(Leeds-Hurwitz, 2009). It further states that knowledge first manifest itself at social level(Vygotsky, 1978) before it narrow down to individuals(Kauchak \& Eggen, 2012). Social constructivists maintain that knowledge can be passed to the society through the sharing or collaboration which cannot be possible if individuals are left to reason and judge for themselves. Individuals which this paper refers to as stakeholders understand phenomena by interacting with other individuals especially the practitioners of a field and the scholars(Amineh \& Hanieh, 2015). Stakeholder in accounting use accounting information reported to make economic decisions, this means that they may make wrong decisions if they are not properly informed. Social constructivism theory is envisaged by this paper to assist universities in creating awareness of social reporting, environmental reporting and economic reporting knowledge to the stakeholders so as to foster a strong sustainability accounting field and practice. The stakeholder are hence capable of scrutinizing expert reports (Belenky, Clinchy, $\&$ Tarule, 1986) for frauds and that only truth should be contained in them.

\section{Sustainability Accounting}

Management accounting is continuing to grow its scope owing to emergence of social, environmental concerns amid depleting natural resources which is a post economic depression menace. Sustainability accounting is hence a system, methods, and processes of forming sustainability information for accountability and informed judgement(Zvezdov \& Schaltegger, 2017). This entails identifying, defining indicators, measuring and communicating integrated information to the stakeholders(Zvezdov \& Schaltegger, 2017). The companies are continuing to lay more emphasis on social dimensions, environmental dimensions and economic dimensions and their interplay, a factor which is shaping governance of accounting information in this dimensions(Eccles, Krzus, \& Serafein, 2012). Even with the intensified involvement by the industry in sustainability issues, some empirical studies have found that accounting professionals and scholars have played very little role in sustainability agenda(Ballou et al. 2012) by creating and disseminating the knowledge to the stakeholders.Still, challenges face the organizations and stakeholders on gauging the information on sustainability accounting due to non-universal standards (Eccles et al. 2012) since there is variation in reporting even within an industry. This paper argues that university accounting professional and accountants' involvement in sustainability accounting knowledge creation and dissemination(Schaltegger, Gibassier, \& Zvedzdov, 2011) will be of great importance in creating standards and maintaining the continuity of this field since the stakeholders themselves will be capable of putting pressure on industries so that the future generation's life is well preserved.

\section{Social Reporting}

Rob and Jan (1997) found that companies need to disclose social information relating to number of employees and the approximate pay, meeting employee needs, concern of disabled employees, arranging for pension, charity and donations. Apart from just reporting on social factors, the organizations need to practically sell in the market safety products, partner with human rights, maintain customer relations and ensure a satisfied workforce, be in good relationship with the government, build good rapport with the community and ensure a a condusive working environment for all employees(CSR Report, 2011). When employees are incorporated in management development activities, there is an increased value of each individual to the organization in accordance with human resource accounting (HRA)(Flamholtz, 
Bukken, \& Hua, 2003). Measuring human capital including intellectual capital (IC)(Gauthrie, Petty, Yongvanich, \& Ricceri, 2000) is of merit in reflection of competitive human capital and being strategic which is achieved by valuing and reporting for it in financial terms(Toulson \& Dewe, 2004). The organizations need to report on human capital related matters like training and development(Vountisjarvi, 2006).

\section{Environmental Reporting}

Environment is the totality of plants, animals, socioeconomics and cultural tenets which include physical factors such as land, air, biological factors, soil and water surrounding human beingsInvalid source specified.. Environmental issues according to (CSR Report, 2011) include environmental protection and improvements, careful resource use that lead to controlling the environmental impact on aspects of quantity of emitted gas, recycling of waste materials Invalid source specified. This leads in using resources to maximize production and so is returns while retaining the status of the environment or evening improving itInvalid source specified. Accountants need to pay attention to environmental pollution prevention prevailing due to economic activities hence budget for costs pollution prevention rather than costs abatementsInvalid source specified.. Vision 2030, medium plans and sustainable development goals advocate for combating climate change, freshwater and protection of wetlands (water management), accounting for natural resources and depreciation of natural resources, soils fertility and depletion, protection of wildlife habitats, air qualityInvalid source specified..

Ahmad (2012) recommends that any environmental expenditure incurred while a company engages in environmental concerns, need to be treated as capital expenditure. This is so because it is from the environment that the business draws its resources that is converted for the purposes of further sales to earn considerable profits. These process can be guided by EMAS which reduces the organization's impact in the environment which also responds to environmental interests of both internal and external stakeholders (Pederson, 2007). Moreover, EMS is a way of complying with the regulations while minimizing costs of audits by customers and magnify market image and still lead to change management which is profitably achieved if SEA reporting is accomplished(Mohamad, Saravanan, \& Seetharaman, 2007).

The conceptual relationship between social constructivism theory, role of university sustainability accounting knowledge creation and dissemination of social reporting, environmental reporting and economic reporting is as shown in Figure 1: 


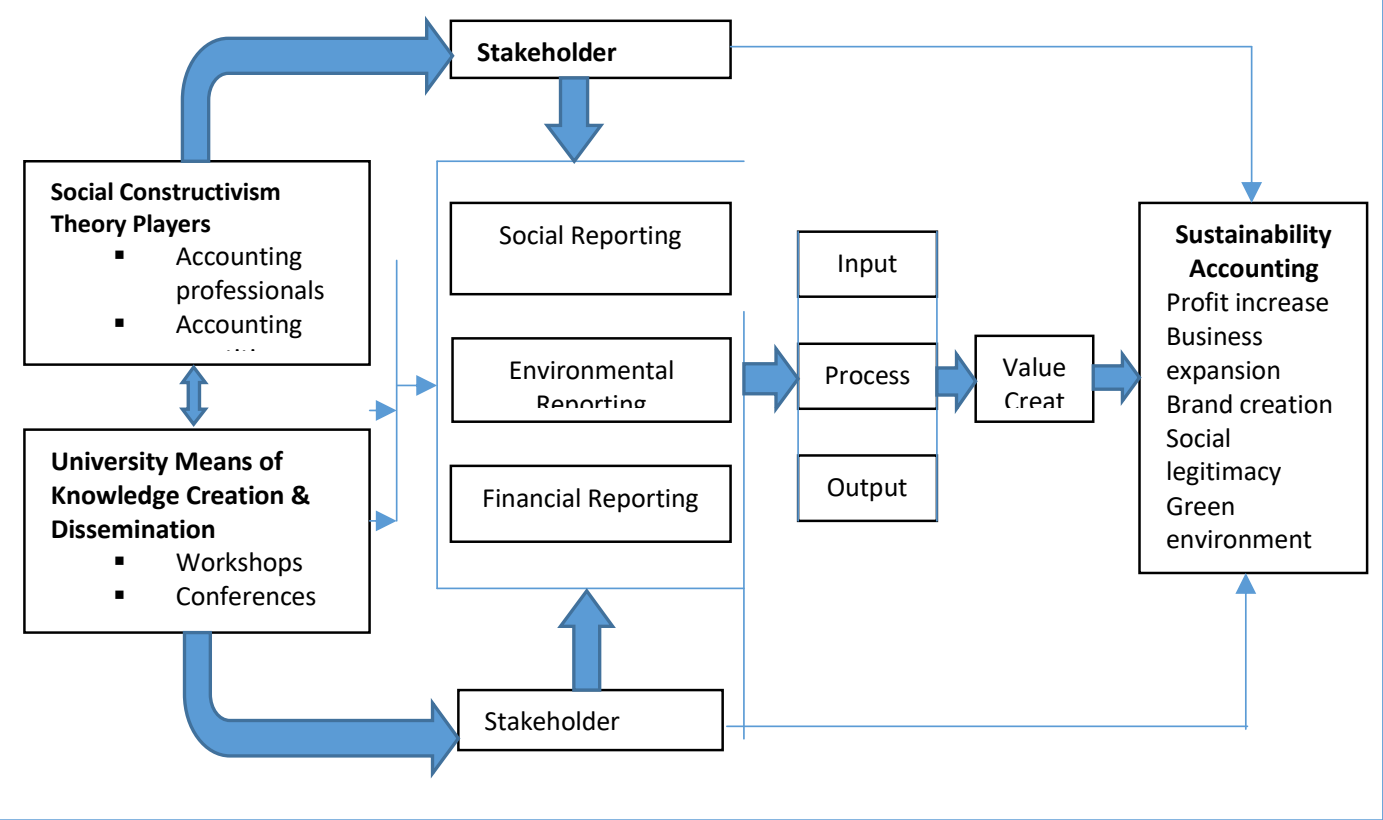

Figure 1: Universities, Social Constructivism Theory, Accounting Education and Stakeholder Knowledge and Sustainability Accounting

Quantitative data was collected from factory unit managers and factory accountants who are the key informants of tea factory's accounting matters. This was aimed at demonstrating the relationship between social reporting, environmental reporting, financial reporting and sustainability accounting where the theory of social constructivism is then discussed on how to foster accounting education through workshops, conferences and seminars which in turn leads to stakeholder knowledge that put pressure on all stages of production that involve financial aspects leading to value creation that build sustainability accounting. The variables: social reporting, environmental reporting, financial reporting were measured in terms of counts of categorical qualitative values which were used to test the relationship with sustainability accounting.

\section{RESEARCH METHODOLOGY}

The study adopted Mixed Method Research (MMR) design which was coiled into existence approximately the year 2000(Lund, 2012). Some researchers like (Venkatesh, Brown, \& Bala, 2013) have also referred to MMR as the third methodological movement which was gaining imminence use among researchers. Adoption of MMR for this study was justified by the fact that it provided greater discernment (Creswell, 2012) in the understanding of SEA Accounting and Reporting and Stakeholders while determining their influence on Sustainability Accounting; assisted in obtaining mass knowledge in order to draw informed conclusions and arrive at future research areas as the researcher was not be pegged on one research design alone (Gail, 2013; Frels \& Onwuegbuzie, 2013). In this context, the study found it even better to term 
MRR as Mixed Method Accounting Research (MMAR), (Ihantola \& Kihn, 2011) as based on the study context.

The study targeted 111 respondents drawn from 37 tea factories around the entire Mount Kenya region. The tea factories included Chinga, Gacharage, Gachege, Gathuthi, Gatunguru, Githambo, Githongo, Gitugi, Igembe, Ikumbi, Imenti, Iriaini, Kagwe, Kambaa, Kanyenyaini, Kathangariri, Kiegoi, Kimunye, Kinoro, Kionyo, Kiru, Makomboki, Mtaara, Michimikuru, Mungania, Mununga, Ndarugu, Ndima, Nduti, Ngere, Njunu, Ragati, Rukuriri, Theta, Thumaita, and Weru. The study sort information from Factory Unit Managers, Factory Accountants, Factory Assistant Accountants or Accounts Clerks drawn from each tea factory. Data was obtained from 68 tea factory unit managers and accountants. The Likert scale data was coded and transformed to categorical qualitative values in which counts were obtained to run binary logistic regression model. Interview schedule was also applied in strengthening the findings of binary logistic regression.

\section{STUDY FINDINGS}

The study findings on respondents' bio-data, descriptive statistics on the cross tabulation of counts between social reporting, environmental reporting and sustainability accounting; and binary regression are presented below:

\section{Respondents' Education Qualification}

The study sort to identify the education level of the respondents so as to gauge their capability to tackle elements of social reporting, environmental reporting and sustainability accounting. The highest educational qualifications were categorized under secondary education and below, diploma, undergraduate, masters and diploma.The results in Figure 2 revealed that majority of the respondents had undergraduate as their highest level of education, followed by masters. Notably, somebody still had less than secondary education as the highest academic qualification, who during interview revealed that had done professional accounting examinations as shown in Figure 2.

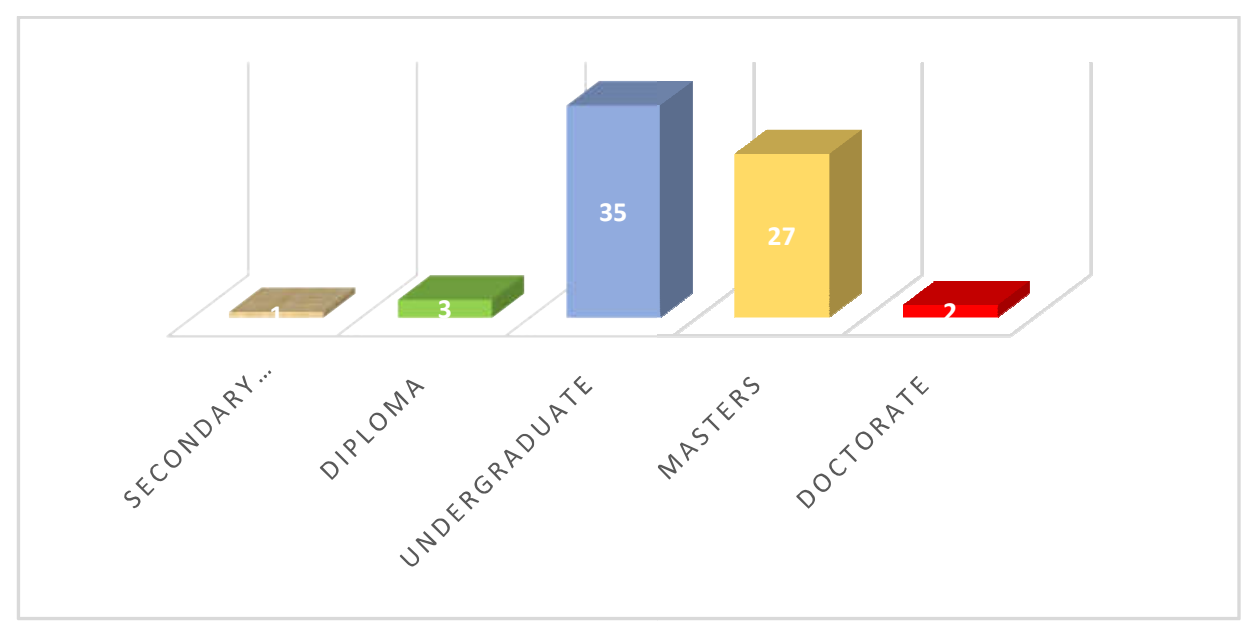

Figure 2: Educational Qualification of the Respondents 
The output showed that most of the respondents had academic qualification to make decision and hence tackle the matter at hand that required one had undergone education in order to interpret sustainability accounting tenets. The significant factor here is that most of the respondents have attained university education of minimally undergraduate level. This indicates that the accounting graduates can handle sustainability accounting knowledge by partnering with the university scholars.

\section{Association between Social Reporting and Sustainability Accounting}

The strength of influence of social reporting was compared with sustenance of sustainability accounting by cross-tabulating the variables. The results in indicated that the respondents who felt that the influence of social reporting was weak, believed that it does not support sustainability accounting. The respondents who felt that the influence of social reporting was weak believed that sustainability accounting was unstainable $(17.6 \% \%)$ none of the respondents believed that it was sustainable. The respondents who felt that the strength of influence of social reporting was strong believed that sustainability accounting was unsustainable $(10.3 \%)$ but a majority $(48.5 \%)$ of them believed that it is was sustainable. Generally, majority of the respondents $(58.8 \%)$ believed that social reporting made sustainability accounting sustainable. The results which are presented in Table 1.

0

It was found out that sustainability accounting was much influenced by increasing strength of social reporting. When social reporting is intensified and constantly practiced, sustainability accounting is greatly improved and its sustainability assured.

\section{Association between Environmental Reporting and Sustainability Accounting}

The study further assessed the how different strength of environmental reporting relate with the sustenance of sustainability accounting. The counts for the measure of environmental reporting was cross tabulated with the counts of the measure of sustainability accounting. The output was presented in a contingency table where sustainability accounting was cross-tabbed by environmental reporting. The results indicated that all the respondents $(n=9)$ who believed that the influence of environmental accounting is weak, also felt that it would make sustainability accounting unsustainable. Out of the 43 respondents that believed that the influence of environmental reporting is strong, $8.8 \%$ felt that even with the strength of influence it would lead to unsustainable practice of sustainability accounting while $54.4 \%$ felt that it would lead to sustainable practice of sustainability accounting. The output is as presented in Table 2 .

\begin{tabular}{lllllll}
\hline \multirow{2}{*}{ 0Strength } & \multicolumn{2}{l}{ Unsustainable } & Sustainable & \multicolumn{3}{c}{ Total } \\
\cline { 2 - 7 } & Frequency & Percentage & Frequency & Percentage & Freq & \% \\
\hline Weak & 9 & 13.2 & 0 & 0.0 & 9 & 13.2 \\
Moderate & 13 & 19.1 & 3 & 4.4 & 16 & 23.5 \\
Strong & 6 & 8.8 & 37 & 54.4 & 43 & 63.2 \\
\hline Total & $\mathbf{2 8}$ & $\mathbf{4 1 . 2}$ & $\mathbf{4 0}$ & $\mathbf{5 8 . 8}$ & $\mathbf{6 8}$ & $\mathbf{1 0 0 . 0}$ \\
\hline
\end{tabular}


The study findings revealed that when the strength of influence of environmental reporting is intensified, then the practice of sustainability accounting is actually sustainable. This is taken into consideration that there are costs incurred and benefits derived from elements of environmental reporting.

\section{Relationship between Social Reporting, Environmental Reporting and Sustainability Accounting}

Simultaneous multiple logistic regression was run in order to test for hypothesis four.The output of the multiple logistic regression showed that when the independent variable are simultaneously entered into the model, results showed that there was a statistically significance influence of social reporting on sustainability accounting $\left(\right.$ Wald $\left.\chi_{(1)}^{2}=4.526, p<\alpha\right)$ at $5 \%$ level of significance. The findings had a positive beta hence showing that increasing strength of social reporting increases sustainability accounting. It was also observed that environmental reporting significantly influence sustainability accounting $\left(\right.$ Wald $\left.\chi_{(1)}^{2}=8.155, p<\alpha\right)$. The Wald's test results are presented in Table 3.

0

The output showed that the association was positive indicating that as social reporting and environmental reporting is intensified, sustainability accounting is assured on an increasing trend.

$$
\log \left\{\frac{\pi(x)}{1-\pi(x)}\right\}=-22.183+2.693 X_{1}+4.090 X_{2}
$$

Where:

$$
\begin{aligned}
& \log \left\{\frac{\pi(x)}{1-\pi(x)}\right\}=\text { Sustainability Accounting } \\
& X=\text { Independent variables } \\
& X_{1}=\text { Social Reporting } \\
& X_{2}=\text { Environmental Reporting }
\end{aligned}
$$

\section{DISCUSSION OF FINDINGS}

The education qualifications of the respondents showed they had enough knowledge of accounting and reporting. The knowledge is part of the management accounting that is crucial in providing sustainability information(Matembele, 2014) for strategic decision making and determining of the influence of externalities' influence on sustainability accounting. This is in consistent with ACCA report by(Hannah, 2010) which stated that accountants are in a better position to deep comprehension of social, environmental and economic issues which focus on long-term accounting practices for the gain of all stakeholders. In order to radicalize the rationality of conventional accounting to sustainability accounting, it is the function of general managers and accountants to play the role of identifying social and environmental risks(Bebbington \& Ian, 2016). This means that the factory unit managers and factory 
accountants can be brought on board through social constructivism knowledge generation and learning towards educating the stakeholders.

The output of the multiple logistic regression showed that when the independent variable are simultaneously entered into the model, there was a statistically significant influence of social reporting on sustainability accounting $\left(\right.$ Wald $\left.\chi_{(1)}^{2}=4.526, p<\alpha\right)$ at $5 \%$ level of significance. The findings had a positive beta hence showing that increasing strength of social reporting increases sustainability accounting. It was also observed that environmental reporting significantly influence sustainability accounting $\left(\right.$ Wald $\left.\chi_{(1)}^{2}=8.155, p<\alpha\right)$. The output showed that the association was positive indicating that as environmental reporting increases, sustainability also increases. It was hence deduced that social reporting and environmental reporting had a significant influence on sustainability accounting. These findings are consistent with research findings by (Ali, 2013)which also found out that sustainability accounting is highly influenced by the choice of social reporting and environmental reporting. It hence observed that social elements, environmental elements and financial elements in accounting both impact the organization either internally or externally and on its flows and stock. The flows are manifested in environmental costs and benefits, social costs and benefits and economic costs and benefits. These methods of reporting have attracted attention of media and other stakeholders on their benefits to the stakeholders themselves hence indicating that they support sustainability accounting(Igwe \& Nwadialor, 2015). There are study findings that contradict the outcome of this study in which social reporting and environmental reporting have simply been categorized as symbolic and not actually the tenets supporting sustainability accounting(Buhr, Gray, \& Milne, 2014). However, the study findings here strongly supported social reporting and environmental reporting as influencing sustainability accounting.

\section{CONCLUSIONS AND RECOMMENDATIONS}

The study supports the theory of social constructivism of knowledge creation and dissemination towards creating accounting education. Sustainability accounting was found to be significantly influenced by social reporting. The social reporting entailled practising social elements of accounting by allocating costs and deriving of benefits by the stakeholders. The study also established that environmental reporting significantly influence sustainability accounting. Environmental reporting was manifested in terms of ecological and energy factors and natural capital extraction. The integrated reporting of social repoting, environmental reporting and economic reporting are expected to benefit the stakeholders. While the study establishes that the factory accountants and factory unit managers bear knoledge on sustainability accounting and the reportings, it is still unclear whether the intended users of these information are aware of them for decision making. It is hence strongly recommended that the universities to intensify accounting education to the stakeholders by way of seminars, workshops and conferences so that the stakeholders are capable of auditing the information they receive apart from using it to make informed decision making.

\section{REFERENCES}

Ali, K. (2013). Sustainability Accounting. What it is and is Not. International Journal of Accounting and Financial Management (IJAMF), 13, 762-736.

Amineh, J. R., \& Hanieh, D. A. (2015). Review of Constructivism and Social Constructivism. Journal of Social Sciences, Literature and Languages, 1(1), 9-16. Retrieved from jssll.blue-ap.org 
Ballou, B., Casey, J. R., Grenier, H. J., \& Heitger, L. D. (2012). Exploring the Strategic Integration of Sustainability Initiatives: Opportunities for Accounting Research. American Accounting Association, 26(2), 265-288. Retrieved from http://doi.org/10.2308/acch-50088

Bebbington, J., \& Ian, T. (2016). Social and Environmental Accounting, Auditing, and Reporting: A Potential Source of Organizational Risk Governance. Sage Journal, 25(1), 38-55.

Belenky, M. F., Clinchy, B. M., \& Tarule, J. M. (1986). Women's Ways of Knowing: The Development of Self, Voice and Mind. New York: Basic Books.

Benn, S., \& Martin, A. (2010). Learning and Change for Sustainability Considered: A Role for Boundary Objects. Academy of Management Learning \& Education, 9(3), 397-412.

Buhr, N., Gray, R., \& Milne, M. J. (2014). Histories, Rationales, Voluntary Standards and Future Prospects for Sustainability Reporting: CSR, GRI, IIRC and Beyond. In J. Bebbington, J. Unerman, \& B. O'Dwyer, Sustainability Accounting and Accountability (pp. 51-71). Loondon, Routledge.

Cheng, B., Laonnis, L., \& Serafeim, G. (2014). Corporate Social Responsibility and Access to Finance. Strategic Management Journal, 35(1), 1-23.

Creswell, J. W. (2012). Education Research: Planning, Conducting and Evaluating Quantitative and Qualitative Research (4th ed.). Boston: Pearson Education International.

CSR Report. (2011). A Study on Awareness of Managers and Consumers in Vietnam. Journal of Accounting and Taxation, 3(8), 162 - 170. doi:10.5897/JAT11.016

Dyllick, T., \& Hockerts, K. (2002). Beyond the Business Case for Corporate Sustainability. Business Strategy and the Environment, 11, 130-141.

Eccles, G. R., Krzus, P. M., \& Serafein, G. (2012). The Need for Sector-Specific Materiality and Sustainability Reporting Standards. Journal of Applied Corporate Finance, 24(2), 65-71. doi:10.1111/j.1745-6622-0038.x

Ernest \& Young (EY). (2014). Sustainability Reporting - the time is now. UK: EYMG Ltd.

Flamholtz, E. G., Bukken, M. L., \& Hua, W. (2003). Measuring the ROI of Management Development: An Application of Stochastic Rewards Valuation Model. Journal of Human Resource Costing and Accounting, 7(1-2), 21-40.

Gauthrie, J., Petty, K., Yongvanich, K., \& Ricceri, F. (2000). Using Content Analysis as a Research Method to Inquire into Intellectual Capital Reporting. Journal of Intellectual Capital, 5(2), 282-293. doi:http://dx.doi.org/10.1108/14691930410533704

Golsorkhi, D., Leca, B., Lounsbury, M., \& Ramirez, C. (2009). Unmasking Domination: On Our Role as Scholars of Practice, Practitioners of Social Science and Publication Intellectuals. Organization, 16(6), 779-797.

Hannah, J. (2010). Sustainability Reporting Matters: What are Governments Doing about it? The Association of Chartered Certified Accountants.

Igwe, N. N., \& Nwadialor, E. (2015). Effectiveness of Corporate Social Responsibility (CSR) Reporting in Enhancing Corporate Image. Eurpoean Journal of Business and Social Sciences, 4(5), 01-11. Retrieved from http://www.ejbss.com/recent.aspx-/

Ihantola, E. M., \& Kihn, L. A. (2011). Threats to Validity in Mixed Methods Accounting Research. Qualitative Research in Accounting and Management, 8(1), 35 - 58. doi:http://dx.doi.org/10.1108/11766091111124694

Kauchak, D., \& Eggen, P. (2012). Learingin and Teaching: Research Based Methods. (V. C. Kelly, \& M. Annalea, Eds.) Boston: Pearson Education Inc.

Leeds-Hurwitz, W. (2009). Social Construction of Reality. Encyclopedia of Communication Theory, 892-895. 
Lin, C.-S., Chang, R.-Y., \& Van, T. D. (215). An Integrated Model to Explain How Coporate Social Responsibility Affects Corporate Financial Perfomance. Sustainability, 7, 82928311. doi:10.3390/su7078292

Lund, T. (2012). Combining Qualitative and Quantitative Approaches. Scandinavian Journal of Education Research, 56(2), 155 - 165. doi:10.1080/00313831.568674

Mandilas, A., Kourtidis, D., Florou, G., \& Valsamidis, S. (2016). Accounting Education and Research in Relation to Business Needs. Scientific Bulletin - Economic Sciences, 15.

Marx, B., \& Van der Watt, A. (2013). Sustainability in Accounting Education: An Analysis of the Teaching thereof at Accredited South African Universities. South African Journal of Accounting Research, 27(1), 59-86. doi:10.1080/10291954.11435171

Matembele, K. (2014). Management Accounting Tools Providing Sustainability Information for Decision Making and Its Influence on Financial Performance. Pretoria.

Milan, Z. (2009). Sustainability Accounting and Reporting. Centre of Economic Studies.

Mohamad, I., Saravanan, A., \& Seetharaman, A. (2007). Environmantal Accounting as a Tool for Environmental Management System. Applied Science Environmental Management, 11(2), 137 - 145. Retrieved from http://www.bioline.org.br/ja

Odhiambo, A. O. (2015). The Effect of Social and Environmental Accounting and Reporting on Financial Performance of Companies Listed on The Nairobi Stock Exchange. Nairobi: University of Nairobi Press.

Parkin, S., Andy, J., Buckland, H., Brookers, F., \& White, E. (2003). Accounting for Sustainability. London.

Pederson, E. R. (2007). Perceptions of Performance: How European Firms Experience Environmental Accounting System. Corporate Social Responsibility and Environmental Management, 61-73.

Reuter, K. E., Juhn, D., Portela, R., \& Venter, J. (2016). Natural Capital Accounting. Gaborone, Botswana.

Robson, G. S., Savage, H. M., \& Schffer, R. J. (2003). Accounting Education: Changing Skill Sets to Meet Modern Needs. Catalyst, 26-29.

Russo, M. V., \& Fouts, P. A. (1997). A Resource Based Perspective on Corporate Environmental Performance and Profitability. Academy of Management Journal, 40(3), 534-559.

Sahd, L., \& Rudman, R. (2012). Sustainability: the Stakeholder Revolution and the SME. Accountancy SA (asa), 26-27.

Schaltegger, S., \& Burritt, R. L. (2010). Sustainability Accounting for Companies. Catchphrase or Decision Support for Leaders. Journal of World Business, 45, 375-384.

Schaltegger, S., Gibassier, D., \& Zvedzdov, D. (2011). Environmental Management Accounting A Bibliometric Literature Review. Luneburg: CSM.

Schneider, A. (2015). Reflexibility in Sustainability Accounting and Management: Transcending the Economic Focus of Corporate Sustainability. Journal of Business Ethics, 127(3), 525536.

Sonja, E. P., Weber, L. J., Wong, A. J., \& Bergner, J. (2016). The Inclusion of Sustainability in the Accounting Curriculum. The CPA Journal.

Supriti, M., \& Damodar, S. (2010). Does Corporate Social Responsibility Influence Firm Performance of India Companies? Journal of Buisness Ethics, 95, 571-601. doi:10.1007/s10551-010-0441-1

Toulson, P. K., \& Dewe, P. (2004). Human Resource Accounting as a Measurement Tool. Human Resource Management Journal, 14(2), 75-90.

United Nations Development Programme (UNDP). (2015). Sustainable Development Goals. New York: UN. 
United Nations General Assembly (UNGA). (2015). Transforming Our World: the 2030 Agenda for Sustainable Development. New York: UN.

Venkatesh, V., Brown, S., \& Bala, H. (2013). Bridging the Qualitative-Quantitative Divide. Management Information System Quarterly.

Vountisjarvi, T. (2006). Corporate Social Reporting in the Europe Context and Human Resource Disclosures. Journal of Business Ethics, 69, 331-354.

Vygotsky, L. S. (1978). Mind in Society. Cambridge: Havard University Press.

Wolcott, K. S. (2010). Sustainability Accounting: What It Is and How to Teach It. San Francisco.

Wright, S., \& Chalmers, K. (2010). The Future of Accounting Academics in Australia. Sydney: Institute of Chartered Accountants of Australia.

Zvezdov, D., \& Schaltegger, S. (2017, September 20). Springer Link. Retrieved from Encyclopedia of Corporate Social Responsibility: https://link.springer.com/referenceworkentry/10.1007\%2F978-3642-28036-8_743 